\title{
ELEKTRONICKÝ OBCHOD S VYUŽITÍM PLATFORMY IBM MAINFRAME A OPERAČNÉHO SYSTÉMU z/OS
}

\author{
Lubomír Bombala*
}

\section{Úvod}

Už viac ako 40 rokov predstavujú systémy IBM mainframe centrálu pre finančné služby a maloobchod. Denne sa vykonajú milióny transakcií práve prostredníctvom tejto infraštruktúry. Mainframy sa stali známe predovšetkým vd’aka svojej mohutnosti, vysokej bezpečnosti a integrite.

$\mathrm{Na}$ začiatku 90. rokov dvadsiateho storočia mnohí odborníci predpovedali skoré odstavenie mainframov. Zdalo sa, že celé IT odvetvie sa zameria na architektúru client/server a distribuované systémy. Zabudlo sa však na to, že účelom IT od samého začiatku bolo adresovat' obchodné problémy a príležitosti. Mnohí si neuvedomili, že v tom samom čase prebiehal vývoj systémov IBM mainframe d’alej, bolo do nich doplnené štandardné UNIXové prostredie, funkcionality webového servera, Java, podpora XML, TCP/IP, firewall a vel'mi dobre prepracovaná virtualizačná technológia [8]. Pokračoval aj vývoj v oblasti súborových systémov, výpočtového výkonu či pamätí. Mainframy si zachovali tradičné silné stránky ako spol'ahlivost', dostupnost' a bezpečnost'.

Systémy IBM mainframe nie sú vhodné pre každú obchodnú aplikáciu, ale sú optimalizované pre vysokú dostupnost' a aplikácie s vel'kým množstvom I/O operácií. Ich nasadenie podporujú aj sprísňujúce sa regulačné a priemyselné štandardy. Ďalší faktor sú náklady na chladenie a napájanie serverových fariem či prevádzku budov. Multiplikovanie serverov spôsobuje vysoké náklady na administráciu a cenu softvéru. Tieto a d’alšie faktory vedú mnohé firmy k pozitívnemu postoju k tejto technológií.

Tento článok popisuje, ako firemný sektor nasadzuje Internet a webové nástroje do svojho podnikania s partnermi, dátovými systémami a na dokončenie transakcií. Ciel'om je uviest' koncepciu využitia operačného systému z/OS ako webového servera a popísat' podstatné možnosti dostupné v operačnom systéme z/OS pre poskytnutie webového prístupu k pre podnikanie citlivým aplikáciám a dátam.

\section{Systém IBM zSeries mainframe}

\footnotetext{
* Ing. L’ubomír Bombala, DHL IT Services Europe, V Parku 2308/10, 14800 Praha 4, ext. doktorand, Katedra spojov, FPEDAS, ŽU v Žiline

tel: +420288 802185

e-mail: lubomir.bombala@dhl.com
} 
Mainframe je klúčový prvok IT infraštruktúry mnohých odvetví, ktoré sú motorom globálnej ekonomiky. V súčasnosti sa mainframy nasadzujú viac ako kedykol’vek predtým. Podnikanie, ktoré vyžaduje vysokú bezpečnost', dostupnost' a spol'ahlivost' pre aplikácie a dáta často závisí na technológii IBM zSeries mainframe, ktorá najčastejšie využíva operačný systém z/OS.

V tomto článku chceme popísat' stručne evolúciu mainframov a vysvetlenie dôvodov, prečo predstavujú vel'mi spol’ahlivú platformu pre prevádzku aplikácií a obchodných dát.

Mnohí si môžu položit' otázku, prečo využívat' mainframy? Aké sú rozdiely medzi operačným systémom z/OS a inými operačnými systémami? Na pochopenie týchto rozdielov je vhodné uviest' trochu z histórie mainframov a ich základnú filozofiu.

\section{Stručná história}

Iba málo odvetví zaznamenalo tak rapídny rozvoj a rast ako odvetvie informačných technológií. Uved'me príklad prechodu od vákuových prvkov cez tranzistory až $\mathrm{k}$ integrovaným obvodom.

Mainframy prešli takisto dlhým vývojom, ktorý môžeme datovat' od roku 1964, kedy bol predstavený IBM System/360. Tento systém bol revolučným krokom vo vývoji počítačov z viacerých dôvodov [3]:

- $\quad$ System/360 dokázal vykonávat’ numericky intenzívne vedecké výpočty, ako aj komerčné výpočty náročné na vstupno-výstupné operácie

- $\quad$ System/360 predstavoval líniu produktov, ktorá priniesla kompatibilitu smerom nahor, tzn. staršie inštalácie sa mohli presunút' na výkonnejšie počítače bez potreby úpravy programov

System/360 využíval dedikované počítače, ktoré riadili vstupno/výstupné operácie, čo dovol’ovalo ústrednej procesorovej jednotke sústredit' výpočtové zdroje na beh aplikácie

Tieto systémy vo svojich začiatkoch disponovali vel'mi malou pamät'ou, napr. niektoré modely System/360 boli prevádzkované s $32 \mathrm{kB}$ pamäte RAM, ktorá musela postačovat' pre aplikáciu i operačný systém. Hardvér i softvér boli optimalizované, aby čo najlepšie využívali obmedzené zdroje.

IBM investovalo miliardy dolárov do vývoja platformy System/360. Operačný systém z/OS, ktorý je v súčasnosti najčastejším operačným systémov na platforme mainframe, má svoje väzby na System/360.

Jeden z operačných systémov, ktorý bežal na System/360, bol OS/360. Jednou $\mathrm{z}$ variant operačného systému OS/360 bol MVT (multitasking with a variable number of tasks). Ked' IBM predstavilo koncepciu virtuálnej pamäte so System/370, bol operačný systém premenovaný na SVS (single virtual storage), čo zdôrazňovalo skutočnost', že existoval jeden virtuálny adresný priestor pre operačný systém a všetkých uživatel'ov. Tento operačný systém bol relatívne rýchlo nahradený verziou operačného systému, ktorý poskytoval oddelený virtuálny adresný priestor pre každého užívatel'a. Táto verzia operačného systému bola nazvaná MVS (multiple virtual storage). Tento operačný systém vyžadoval pre svoju prevádzku viacero od operačného systému nezávisle inštalovaných subsystémov. Neskôr sa IBM rozhodlo niektoré z kl'účových subsystémov integrovat' do inštalácie operačného systému MVS a výsledný produkt dostal názov operačný systém OS/390, ktorý je priamy predchodca operačného systému z/OS. Operačný systém z/OS je už 64-bitový operačný systém, do ktorého boli v porovnaní s OS/390 integrované niektoré nové funkcie.

\section{Prečo sú mainframy odlišné?}


Mainframy boli od začiatku navrhnuté pre vel'ké objemy obchodných transakcií a boli počas viac ako 40 rokov kontinuálne zdokonal'ované, aby splnili požiadavky spracovania vel'kého objemu obchodných dát. Žiadna iná súčasná výpočtová platforma nedokáže manipulovat' rozličnými tokmi dát lepšie ako mainframe.

Nie sú však iné počítače lacnejšie, rýchlejšie a jednoduchšie na ovládanie? Odpoved' na túto otázku nie je jednoznačná. Študent, ktorý píše svoju semestrálnu prácu, má úplne iné požiadavky na výkon a objem spracovaných dát ako banka, ktorá potrebuje uskutočnit' milióny transakcií každý deň, nehovoriac o požiadavke, že banka musí absolvovat' bezpečnostný a účtovný audit.

Mainframy nie sú správnym riešením pre každú výpočtovú úlohu. Podniky siahajú po mainframoch a operačnom systéme z/OS, ked' potrebujú spracovat' vel'ké objemy dát, vel'ké objemy transakcií, ked' majú požiadavky na presun vel'kého množstva dát, potrebu vysoko spol'ahlivého systému a vel'ké množstvo odlišných typov spracovávaných úloh, ktorých spracovanie bude najefektívnejšie, pokial' budú umiestnené na rovnakom serveri. Práve v takýchto prípadoch dokazujú mainframy svoje prednosti.

\section{Mainframe verzus Client/Server}

V architektúre client/server typicky kooperuje viac serverov, aby vykonali jednotlivú úlohu. Napr. na obr. č. 1. aplikácia využíva webový server, databázový server a LDAP server.

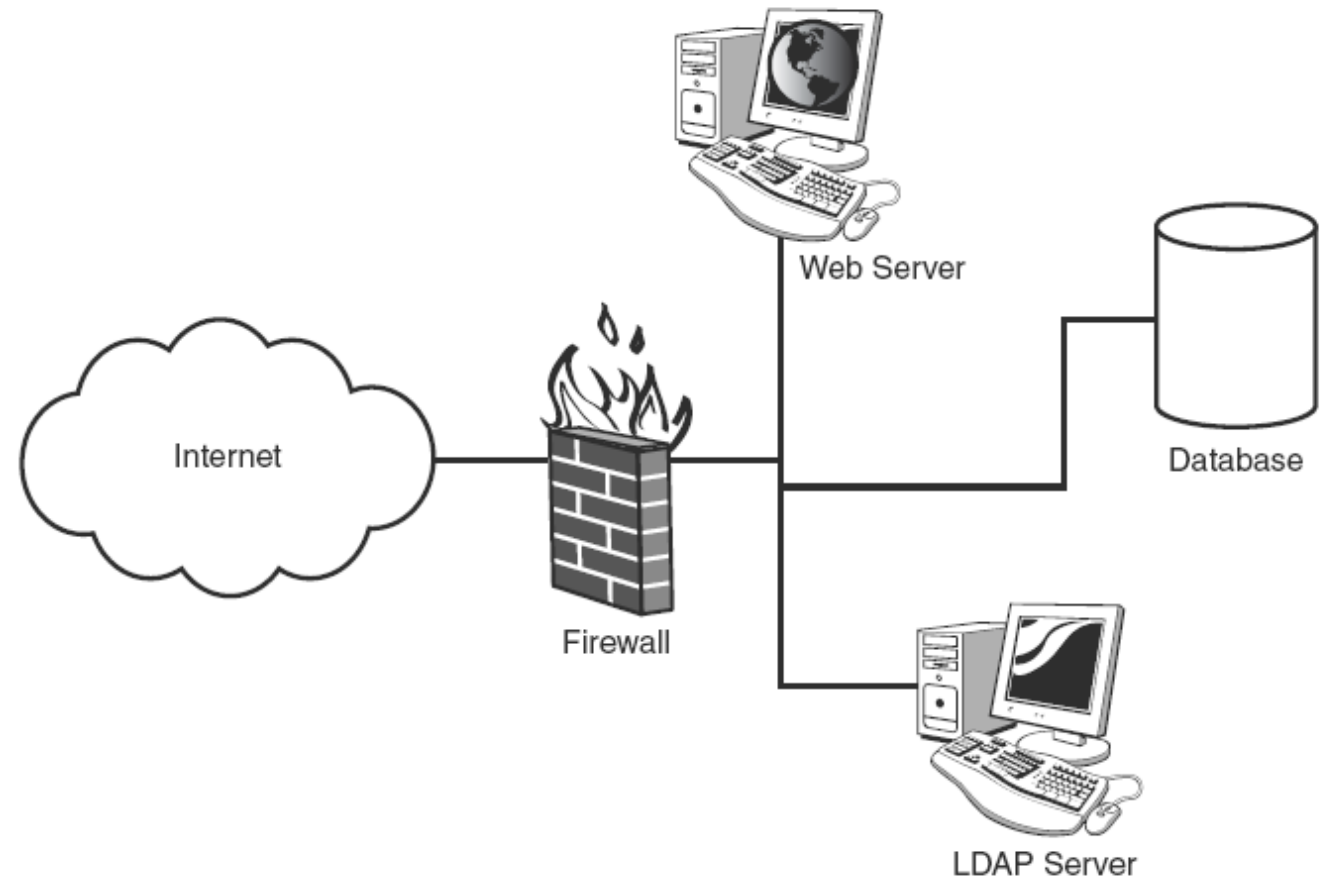

Obr. č. 1: Architektúra client/server (zdroj [3])

Pri architektúre mainframe sa všetky činnosti vykonávajú na jednom serveri. Jeden bezpečnostný subsystém (najčastejšie IBM RACF, ale aj CA Top Secret a CA ACF2) chráni jedno jadro operačného systému. Mainframové subsystémy vykonávajú všetky d’alšie činnosti.

Ako môžeme vidiet' na obr. č. 2. UNIX System Services poskytujú funkcionalitu webového servera. LDAP identity store plní funkcie LDAP servera. DB2 Database plní funkcie databázového servera, pričom namiesto DB2 je možné nasadit' aj systémy ako IBM IMS, CA Datacom, CA IDMS či Oracle for z/OS. Na mainframe sa prevádzkujú relačné i hierarchické databázové systémy. 


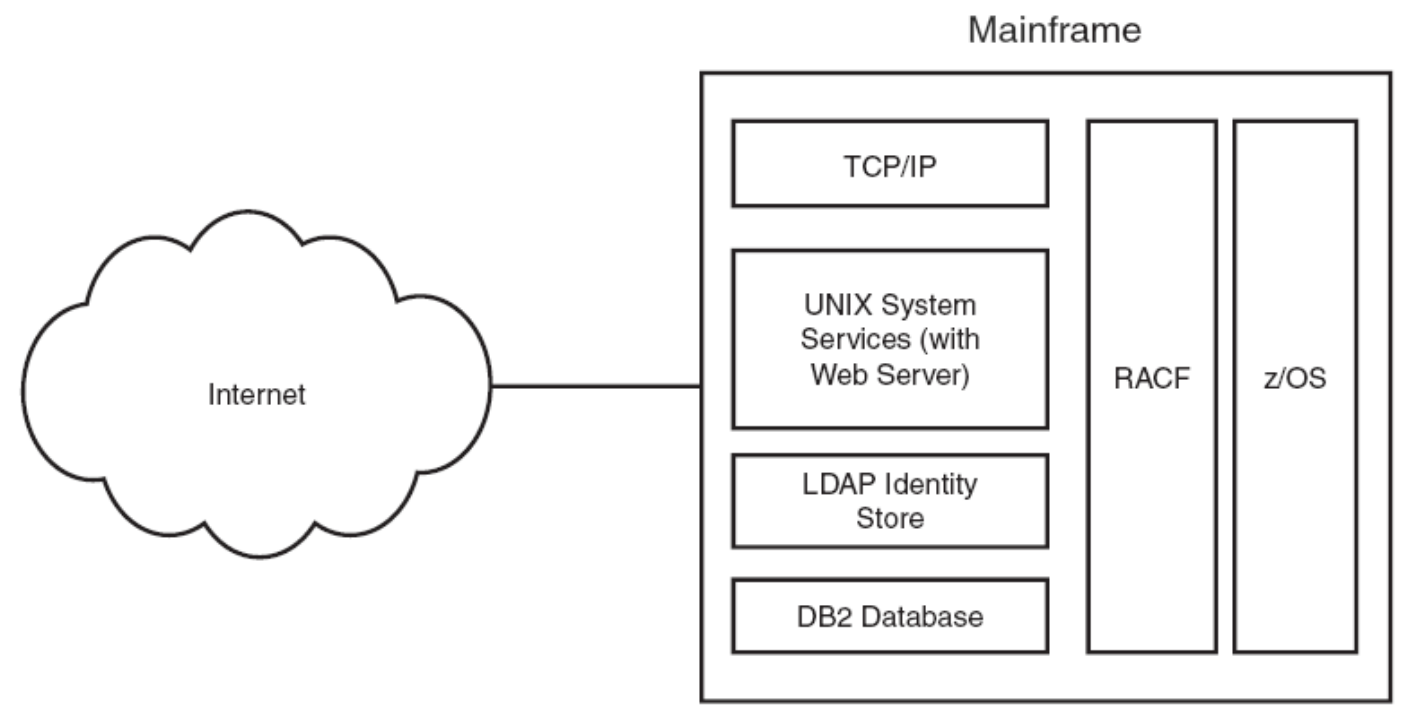

Obr. č. 2: Architektúra mainframe (zdroj [3])

\section{Čo je elektronický obchod?}

Z množstva definícií elektronického obchodu uvedených v literatúre [1], môžeme pre potreby tohto článku vybrat' definíciu, ktorá rozumie elektronický obchod, ako využitie Internetu a d'alších digitálnych technológií pre komunikáciu v organizácii, koordináciu a manažment firmy (Laudon a Laudon, 2002).

Elektronický obchod musí poskytovat' rozsiahle pokrytie. Zahŕňa oblasti od Manažmentu vzt’ahov so zákazníkmi (CRM) až k Manažmentu siete dodávatel'ov (SCM). Úspešný elektronický obchod zahŕňa viac než len dobrú e-commerce stratégiu. Zahŕňa tiež transakcie a spojenia medzi zamestnávatel'om a zamestnancami, medzi zamestnancami v inštitúcii a medzi dodávatel'mi, distribútormi a zákazníkmi.

\section{Prečo sa zaoberat' elektronickým obchodom na operačnom systéme z/OS?}

V dôsledku viacerých dôležitých faktorov sa stáva trh stále dynamickejším. Tieto faktory sú dôsledkom zmien pri vnímaní elektronického obchodu. Medzi takéto faktory patria:

- $\quad$ Fúzie a akvizície spoločností, často ako dôsledok globalizácie, firmy sa preto zaoberajú otázkou, ako integrovat' oddelené a odlišné IT prostredia

- Integrovanie komplexných aplikácií ako napr. ERP od rozličných dodávatel'ov, toto si vyžaduje riešit' problém kombinácie takýchto komplexných aplikácií s IT systémami a novými Internetovými aplikáciami

- V Vzrastajúca konkurencia, význam a vplyv zákazníka zvyšujú dôraz na nástroje Manažmentu vzt'ahov so zákazníkom (CRM), preto je potrebné integrovat' obchodné systémy tak, aby poskytovali jednotný pohl'ad na zákazníka a ponúkali spôsoby hl'adania nových možností podnikania so súčasným zákazníkom

- $\quad$ Tlak na náklady a inovácie si vyžaduje dôraz na manažment dodávatel'ov: ako zlepšit' obchodné procesy a zefektívnit' interakciu so zákazníkmi a dodávatel'mi

- Dôležitá je aj otázka, ako automatizovat' a integrovat' obchodné procesy tak, aby boli dáta dostupné kedykol'vek a kdekol'vek je to potrebné

- Dôležitý je aj faktor, ako obchodovat' na webe, aby firma zostala konkurencieschopná 


\section{Aplikačný rámec pre elektronický obchod}

Aplikačný rámec pre elektronický obchod je integrovaná a konzistentná sústava aplikačných programových interfejsov, protokolov, služieb a konvencií, ktorá poskytuje otvorený, štandardizovaný, škálovatel'ný a úplný základ pre vývoj a rozmiestnenie elektronického obchodu [8]. Na základe aplikačného rámca môžeme zostavit' aplikačný model pre elektronický obchod znázornený na obr. č. 3.

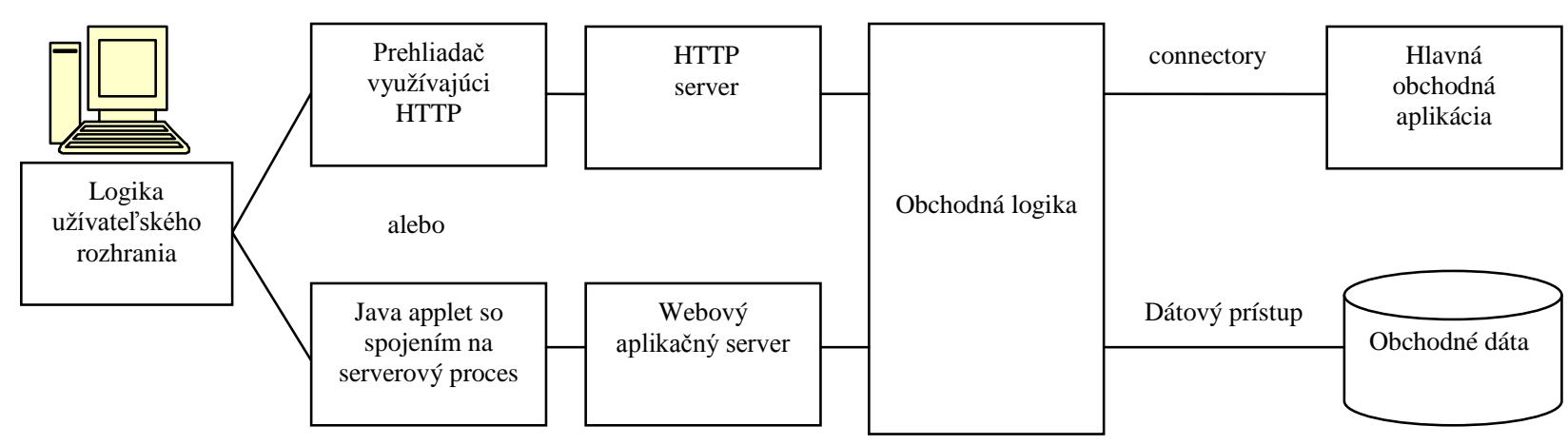

Obr. č. 3: Aplikačný model pre elektronický obchod (zdroj [8] po úprave)

Aplikačný rámec pre elektronický obchod má nasledovné vlastnosti:

- J Jednoduchý klient na strane užívatel'a - webové prehliadače sú podporované ako uživatel'ské rozhranie

- $\quad$ Servero-centrický - toto riešenie znamená, že existuje jeden bod aplikačnej údržby, čo má vplyv na celkové náklady na vlastníctvo tohto riešenia

- $\quad$ Postavený na technológii Java - znamená použitie Java klientov a Javy na webovom aplikačnom serveri. Applet predstavuje Java program spúštaný vo webových prehliadačoch s podporou Javy

- $\quad$ Connectory - poskytujú transparentný prístup k transakciám a dátam riadeným najčastejšie inštalovanými mainframovými subsystémami. Využívajú mainframové prostriedky hlavnej obchodnej aplikácie a vel'ké množstvo podnikových dát

- $\quad$ Topológia rámca je flexibilná - môže byt' zostavený vo viacerých úrovniach

\section{HTTP Server}

IBM integrovalo HTTP server do operačného systému z/OS, pričom tento HTTP server ponúka komplexnú funkcionalitu webového servera. HTTP server je čast'ou platformy WebSphere, preto sa niekedy označuje ako WebSphere HTTP server. Webový server získava dokumentáciu (webové stránky) z UNIXových súborov alebo vlastných systémových dát a vracia ich klientovi. Klient môže takisto spustit' aplikáciu na operačnom systéme z/OS. Tieto aplikácie zahŕňajú:

- $\quad$ UNIXové aplikačné programy umiestnené na operačnom systéme z/OS sú spúšt’ané prostredníctvom Common Gateway Interfejsu (CGI)

- $\quad$ HTTP server vyžaduje od WebSphere Application Servera spustenie Java aplikácie nazývanej servlet. Servlet je aplikácia, ktorá beží na Java serveroch

- Vlastné aplikácie ako napr. CICS (transakčný server pre z/OS. Zabezpečuje činnosti ako: príjem správ $\mathrm{z}$ terminálu, prístup $\mathrm{k}$ dátam na čítanie alebo zápis a následné 
odoslanie odpovede na terminál), IMS transakcie, ako aj procedúry DB2 sú prístupné prostredníctvom connectorových programov

Funkcionalita HTTP servera zahŕňa:

- Samotné načítavanie stránok

- Zaistenie bezpečnej relácie a bezpečný prístup k dátam na operačnom systéme z/OS a programom

- $\quad$ Schopnost' podporovat' viac webových ,images“ na jednom systéme

- Využitie vlastností z/OS, ako je jednoduchá škálovatel'nost', vel'ké pamäte cache, I/O priepustnost' a vynikajúca dostupnost'

\section{WebSphere Aplikačný server}

Štruktúru IBM WebSphere Aplikačného servera pre operačný systém z/OS môžeme znázornit' graficky na obr. č. 4.

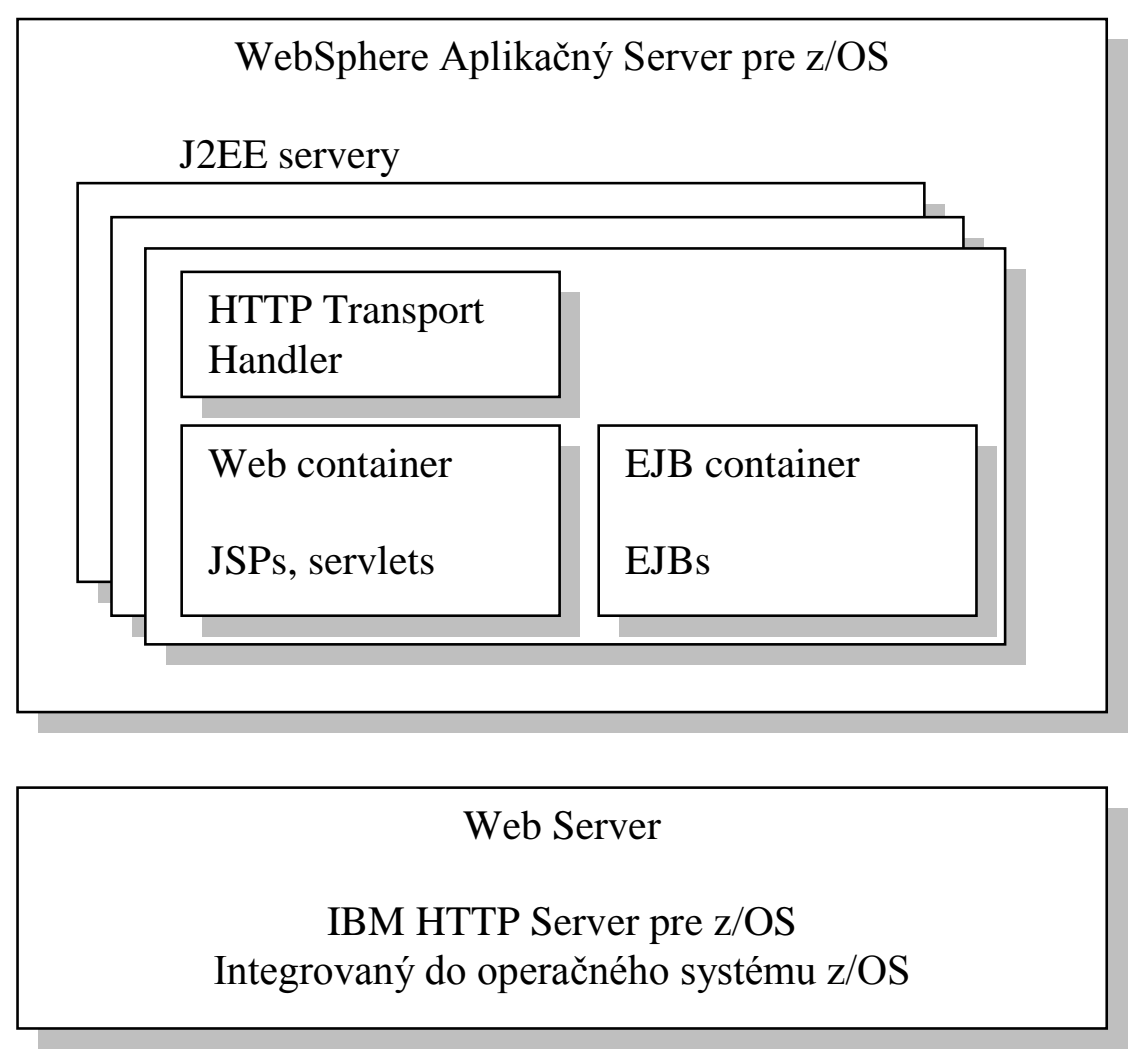

Obr. č. 4. : WebSphere Aplikačný Server pre operačný systém z/OS (zdroj [8])

WebSphere Application Server pre z/OS poskytuje vysoko dostupné, bezpečné, spol'ahlivé a škálovatel'né prostredie pre spúšt'anie Java 2 Enterprise Edition (J2EE) aplikácií a podporuje J2EE aplikácie prostredníctvom J2EE servera.

JSP (Java Server Pages) môžu dynamicky vytvárat' servlety. Sú to webové stránky vytvárané na strane servera s podporou Javy, pričom umožňujú, aby Java a Java Beans boli zahrnuté do HTML stránok dynamicky [7].

Java Bean predstavuje softvérový komponent napísaný v jazyku Java, ktorý sa využíva pri tvorbe programu a dá sa s ním vizuálne manipulovat' vo vývojovom nástroji.

EJB (Enterprise Java Bean) je Java komponent, ktorý môže byt' kombinovaný s d'alším EJB a d’alšími Java komponentmi na vytvorenie distribuovanej aplikácie. EJB predstavuje objektovo-orientovanú technológiu používanú na reprezentáciu obchodnej logiky a na zabezpečenie prístupu k nejavovským systémom a dátam. 
Enterprise beans sa spúšt’ajú v EJB containeri a webové aplikácie (JSPs a servlety) bežia vo webovom containeri. Toto usporiadanie zodpovedá špecifikácii J2EE.

Ked' príde požiadavka od klienta z HTTP servera, bude spracovaná servletom alebo JSP vo webovom containeri. Servlet sa dá prirovnat' k statickému programu, zatial' čo JSP dynamicky generuje program, ktorý sa spustí. Typicky je potom volané EJB v EJB containeri, ktoré môže volat' d’alšie z/OS subsystémy ako napr. DB2, CICS alebo IMS. EJB zaobstaráva obchodnú logiku, kým servlet a JSP riadia prezentačnú logiku pre požiadavky klienta.

HTTP transport handler je alternatívou k IBM HTTP serveru pre z/OS pre prácu S J2EE.

Hlavné výhody implementácie webového servera na platforme z/OS v porovnaní s inými platformami [8]:

- Mainframe je vel'mi dobre škálovatel'ná hardvérová platforma od malého CMOS boxu až po vel'ký paralelný sysplex

- $\quad$ Bezpečnost' je vel'mi silnou stránkou tejto platformy

- V Viac ako 60 percent svetových obchodných dát leží na úložných systémoch platformy mainframe

Ak je webový server prevádzkovaný na tej istej platforme ako vlastné dáta z/OS subsystémov, potom poskytuje priamy prístup k týmto dátam z webového servera.

\section{Postoj firiem k využitiu platformy IBM mainframe pre elektronický obchod}

Mnohé spoločnosti z oblasti bankovníctva, poist'ovníctva či priemyslu riešia dva problémy. Na jednej strane investovali obrovské množstvo prostriedkov do obstarania a správy mainframových systémov, kde je podl'a správy Hurwitz Group uložených viac ako 60 percent korporátnych dát [4]. Takéto spoločnosti závisia na spol'ahlivosti a flexibilnosti mainframov, pretože na nich prevádzkujú kl’účové obchodné aplikácie. Na druhej strane tieto spoločnosti hl'adajú spôsoby využitia možností Internetu implementovaním nových a výkonných aplikácií pre elektronický obchod.

"Mainframy stále prevádzkuje vel'ké množstvo najväčších a najsilnejších spoločností súčasnosti," povedala Kate Mitchell [5], senior vice president pre Marketing a Business Development spoločnosti SeeBeyond. "Toto je obrovská príležitost' pre SeeBeyond mat' vplyv na tieto spoločnosti, využit' technické inovácie dostupné pre elektronický obchod a umožnit' im zostat' agilnými v silne konkurenčnej Internetovej ekonomike." Preto mnohé spoločnosti prichádzajú s riešeniami, ktoré im umožňujú stavat' na investíciách do mainframov a zabezpečit' ich kompletné prepojenie s d'alšími platformami, vrátane Internetu, vo vnútri spoločnosti, ale aj smerom von k zákazníkom.

\section{Záver}

Pri tvorbe riešení pre elektronický obchod musia brat' spoločnosti do úvahy ich existujúcu IT infraštruktúru, rozhodnút' sa, ktoré zdroje sú potrebné pre elektronický obchod a determinovat' optimálny spôsob integrácie s novými technológiami. Kl'účové obchodné pravidlá obsiahnuté $\mathrm{v}$ softvéri, ktoré boli profitabilné $\mathrm{v}$ minulosti a boli vytvorené generáciami softvérových inžinierov v mainframových systémoch, musia byt' integrované $\mathrm{s}$ novými technológiami. Toto je dôvod, prečo sa Java so svojou flexibilitou, interoperabilitou a platformovou nezávislost'ou stala integrálnou súčast'ou nového modelu pre elektronický obchod.

Realitou sú dnes webové riešenia postavené na integrácii mainframov, midrange serverov a minipočítačov. Pôvodné mainframové aplikácie dostávajú novú úlohu bez ohl’adu na to, či sú súčast'ou korporátneho intranetu alebo Internetu. 
V súčasnosti by sa dalo hovorit' aj o renesancii mainframových systémov vd'aka tomu, že vývoj tejto technológie jej umožňuje adaptovat' sa na obchodné trendy [6]: konsolidácia a virtualizácia nasadzujúca virtuálne Linuxové serveri na mainframe dovol'uje firmám využit' existujúce znalosti a investície do osvedčenej platformy a prevádzkovat' rozličné aplikácie vo vysoko dostupnom, spol'ahlivom a bezpečnom prostredí.

Platforma mainframe je kl'účová pre podnikanie spoločnosti IBM. IBM pokračuje v investovaní vel'kého množstva prostriedkov do d’alšieho vývoja a vytvára iniciatívy s partnermi a univerzitami.

Spoločnosti si opät' začali uvedomovat' prednosti mainframovej platformy, ako sú: zdiel'anie dát, obnova pri poruchách, podpora Linuxu, partitioning, výkon, chladenie, manažment serverového poolu a spracovávaných úloh, priority pre jednotlivé procesy, bezpečnost', špecializované procesory, celková vyt'aženost' systému a virtualizácia (umožňuje prevádzkovat' virtuálne viac Linuxových serverov na mainframe, ktoré si môžu vymieňat' dáta $\mathrm{s}$ tradičnými mainframovými aplikáciami). Všetky tieto atribúty sú kl'účové v dnešnom nákladovo a výkonovo orientovanom IT prostredí.

\section{Literatúra a použité zdroje:}

1. Anumba C. J. a Ruikar K.: e-Business in Construction, Blackwell Publishing Ltd., 2008, ISBN 978-1-4051-8234-8

2. Laudon, K.C. a Laudon, J.P. (2002) Management Information Systems, 7th edition.,Prentice-Hall, New Jersey and London.

3. Pomerantz, Ori. a kol.: Mainframe basics for security professionals : getting started with RACF, IBM Press Boston, 2008, ISBN 0-13-173856-9

4. http://www.thefreelibrary.com/Vitria+Extends+Benefits+of+Ebusiness+Platform+to $+t$ he+Mainframe\%3B...-a066697084

5. http://www.allbusiness.com/technology/software-services-applications/60291681.html

6. http://www.appsinsight.net/2008/02/06/the-mainframe-renaissance/

7. http://java.sun.com/

8. www.ibm.com 